\title{
Yield and Quality Parameters as Influenced by Nutrient Management Studies in Sweet Corn
}

\author{
T. Kavya*, B. Venkateswarlu, P.V.N. Prasad and P.R.K. Prasad \\ Department of Agronomy, Agricultural College, Acharya N. G. Ranga Agricultural \\ University, Bapatla, Andhra Pradesh - 522101, India \\ *Corresponding author
}

\section{A B S T R A C T}

\begin{tabular}{|l|}
\hline Ke y w or d s \\
$\begin{array}{l}\text { Green manure, } \\
\text { Sweet corn, Fertility } \\
\text { levels }\end{array}$ \\
\hline Article Info \\
\hline $\begin{array}{l}\text { Accepted: } \\
\text { 06 September } 2018 \\
\text { Available Online: } \\
\text { 10 October } 2018\end{array}$ \\
\hline
\end{tabular}

\section{Key words}

Green manure, Sweet corn, Fertility levels

\begin{abstract}
A field experiment was conducted at the Agricultural College Farm, Bapatla, during kharif 2017 to study the effect of five phosphorus levels to sunhemp as preceding green manure which was incorporated at 50\% flowering stage with four replications was analysed in RBD design and four nitrogen levels to succeeding sweet corn crop was analysed in split plot design with four replications. The effect of phosphorus levels to preceding sunhemp green manure crop to succeeding sweet corn with different levels of nitrogen was analysed. The results revealed that application of $40 \mathrm{~kg} \mathrm{P}_{2} \mathrm{O}_{5} \mathrm{ha}^{-1}$ to preceding sunhemp green manure crop significantly recorded highest yield and quality parameters viz., green cob yield with husk, green cob yield without husk, green fodder yield at harvest, crude protein, crude fibre and total ash content at harvest in both straw and grain. Among the nitrogen levels to sweet corn recorded highest yield attributes and quality parameters were recorded at $120 \mathrm{~kg} \mathrm{~N} \mathrm{ha}^{-1}$.
\end{abstract}

\section{Introduction}

Due to intensive farming, the farmer do not get sufficient time gap to grow green manures. Farmers are not ready to sacrifice the main crop for the sake of growing green manure crop and incorporate it.

However, if a green manure crop is grown with the early showers and incorporated before sowing of kharif crop, it will add considerable quantity of biomass to the soil. Leguminous green manuring crop respond well to phosphorus fertilization because nodulation and nitrogen fixation require high $\mathrm{P}$ status in host plant which can be facilitated by mycorrhizal symbiont. Sweet corn production requires soil nitrogen in high quantities to meet its growth and yield requirements, as this crop partitions more $\mathrm{N}$ to the grain than any other nutrient derived from the soil.

Supply of nitrogen through fertilizers alone is costly. Hence application of green manure to the soil enhances the $\mathrm{N}$ availability to sweet corn.

\section{Materials and Methods}

The field experiment entitled "Yield and quality parameters as influenced by Nutrient 
management studies in sweet corn" was conducted at the Agricultural College Farm, Bapatla during kharif, 2017. The soil was sandy clay loam in texture, slightly saline in reaction $(0.5 \mathrm{EC})$, Neutral $(7.3 \mathrm{pH})$, low in organic carbon $(0.3 \%)$, low in available nitrogen $\left(188.8 \mathrm{~kg} \mathrm{ha}^{-1}\right)$, medium in available phosphorus (30.7 $\mathrm{kg} \mathrm{ha}^{-1}$ ) and high in potassium (282.2 $\left.\mathrm{kg} \mathrm{ha}^{-1}\right)$.

Twenty treatment combinations comprising five phosphorus levels to preceeding green manure crop $\mathrm{P}_{0}$ - Control $\mathrm{P}_{1}-10 \mathrm{~kg} \mathrm{P}_{2} \mathrm{O}_{5}$ ha $^{-1}$, $\mathrm{P}_{2}-20 \mathrm{~kg} \mathrm{P}_{2} \mathrm{O}_{5}$ ha $^{-1}, \mathrm{P}_{3}-30 \mathrm{~kg} \mathrm{P}_{2} \mathrm{O}_{5}$ ha $^{-1}, \mathrm{P}_{4}$ $40 \mathrm{~kg} \mathrm{P}_{2} \mathrm{O}_{5} \mathrm{ha}^{-1}$ and four nitrogen levels to sweet corn $\mathrm{N}_{1}-60 \mathrm{~kg} \mathrm{~N} \mathrm{ha}^{-1}, \mathrm{~N}_{2}-80 \mathrm{~kg} \mathrm{~N}$ $\mathrm{ha}^{-1}, \mathrm{~N}_{3}-100 \mathrm{~kg} \mathrm{~N} \mathrm{ha}^{-1}, \mathrm{~N}_{4}-120 \mathrm{~kg} \mathrm{~N}^{-1}$ in Main plots and Sub plots were tested in split plot design with four replications.

The recommended dose of $120 \mathrm{~kg} \mathrm{~N}, 60 \mathrm{~kg}$ $\mathrm{P}_{2} \mathrm{O}_{5}$ and $60 \mathrm{~kg} \mathrm{~K}_{2} \mathrm{O}$ were applied through SSP and MOP as a basal application. Nitrogen was applied through urea in two splits as per the treatments.

The weather conditions during the crop growth period were normal. The mean maximum and minimum temperature recorded during crop period were $32.0^{\circ} \mathrm{C}$ and $22.9^{\circ} \mathrm{C}$ respectively. The mean maximum and minimum relative humidity is 82.1 and 69.6 respectively.

The crop was planted with a spacing of $60 \times$ $20 \mathrm{~cm}$. The plot size was $6.4 \mathrm{~m} \times 6 \mathrm{~m}$ and 5.2 $\mathrm{m} \times 3.6 \mathrm{~m}$ respectively. Weeding and plant protection measures were followed as and when needed. Observations regarding the periodical growth and yield attributing characters, cob and fodder yield were recorded.

The data were analysed statistically by adopting the standard procedures described by Gomez and Gomez (1984).

\section{Results and Discussion}

\section{Yield}

Regarding yield (Table 1), increased with increase in $\mathrm{P}_{2} \mathrm{O}_{5} \mathrm{~kg}^{-1}$ ha ${ }^{-1}$ preceeding green manure crop. Significant improvement in overall growth of the crop by virtue of increased phosphorus doses. This greater availability of photosynthates, metabolites and nutrients to develop reproductive structure seems to have resulted in increased productive plants, with the phosphorus levels to green manure crop.

Whereas, among the nitrogen levels to sweet corn with increase in the level of nitrogen to sweet corn from 60 to $120 \mathrm{~kg} \mathrm{~N} \mathrm{ha}^{-1}$, the green cob (with husk) yield increased significantly. The green cob yield recorded with application of $120 \mathrm{~kg} \mathrm{~N} \mathrm{ha}\left(13,653 \mathrm{~kg} \mathrm{ha}^{-1}\right)$ was significantly higher over $60 \mathrm{~kg} \mathrm{ha}^{-1}$ and was on a par with 100 and $80 \mathrm{~kg} \mathrm{~N} \mathrm{ha}^{-1}$ and the lowest green cob yield $\left(12,543 \mathrm{~kg} \mathrm{ha}^{-1}\right)$ was observed with application of $60 \mathrm{~kg} \mathrm{~N} \mathrm{ha}^{-1}$. The highest green cob yield (without husk) 11,966 $\mathrm{kg} \mathrm{ha}^{-1}$ recorded with $120 \mathrm{~kg} \mathrm{~N} \mathrm{ha}^{-1}$ applied to sweet corn which was significantly superior over $100,80 \mathrm{~kg} \mathrm{~N} \mathrm{ha}^{-1}$ and $60 \mathrm{~kg} \mathrm{~N} \mathrm{ha}{ }^{-1}$. The lowest green cob yield without husk $(10,734$ $\mathrm{kg} \mathrm{ha}^{-1}$ ) was recorded with $60 \mathrm{~kg} \mathrm{~N} \mathrm{ha}^{-1}$.

Application of $120 \mathrm{~kg} \mathrm{~N} \mathrm{ha}{ }^{-1}$ significantly enhanced the green fodder yield $(17,218 \mathrm{~kg}$ $\mathrm{ha}^{-1}$ ) which was on par with 100 and $80 \mathrm{~kg} \mathrm{~N}$ $\mathrm{ha}^{-1}$. The positive response to higher level of nitrogen on green cob yield could be ascribed to overall improvement in crop growth that enabled the plant to absorb more nutrients, moisture, higher light interception and increased leaf area which might have enabled the plants to accumulate more quantities of photosynthates in the sink Similar findings was also reported by kar et al., (2006) Bhatt et al., (2012) Singh et al., (2012) Shankar et al., (2013) and Eajaz et al., (2014). 
Table.1 Yield of sweet corn as influenced by phosphorus levels to preceeding green manure crop and nitrogen levels to sweet corn

\begin{tabular}{|c|c|c|c|}
\hline Treatment & $\begin{array}{l}\text { Green cob yield } \\
\text { with husk }\end{array}$ & $\begin{array}{l}\text { Green cob yield } \\
\text { without husk }\end{array}$ & $\begin{array}{l}\text { Green Fodder } \\
\text { yield }\end{array}$ \\
\hline \multicolumn{4}{|c|}{ Main plots - Phosphorus levels $\left(\mathrm{kg} \mathrm{ha}^{-1}\right)$ to sunhemp } \\
\hline Control & 9512 & 8343 & 14778 \\
\hline 10 & 11540 & 9567 & 15014 \\
\hline 20 & 13836 & 12288 & 16887 \\
\hline 30 & 14248 & 12309 & 16962 \\
\hline 40 & 15331 & 13520 & 18461 \\
\hline SEm \pm & 476.4 & 239.3 & 496.9 \\
\hline $\mathrm{CD}(\mathrm{P}=0.05)$ & 1468.1 & 737.6 & 1531.3 \\
\hline $\mathrm{CV}(\%)$ & 14.7 & 8.5 & 12.1 \\
\hline \multicolumn{4}{|c|}{ Sub- plots - Nitrogen levels $\left(\mathrm{kg} \mathrm{ha}^{-1}\right)$ to sweet corn } \\
\hline 60 & 12543 & 10734 & 15235 \\
\hline 80 & 12675 & 11176 & 16352 \\
\hline 100 & 12703 & 10946 & 16877 \\
\hline 120 & 13653 & 11966 & 17218 \\
\hline SEm \pm & 498.3 & 218.2 & 507.6 \\
\hline $\mathrm{CD}(\mathrm{P}=0.05)$ & 1424.3 & 623.7 & 1451.0 \\
\hline CV (\%) & 17.2 & 8.7 & 13.8 \\
\hline \multicolumn{4}{|l|}{ Interaction $(\mathbf{P} \times \mathbf{N})$} \\
\hline SEm \pm & 1114.2 & 488.0 & 1135.2 \\
\hline $\mathrm{CD}(\mathrm{P}=0.05)$ & NS & NS & NS \\
\hline
\end{tabular}


Table. 2 Crude protein (\%) of sweet corn as influenced by phosphorus levels to preceding green manure crop and nitrogen levels to sweet corn

\begin{tabular}{|c|c|c|}
\hline \multirow[t]{2}{*}{ Treatment } & \multicolumn{2}{|c|}{ Crude protein } \\
\hline & Straw & Grain \\
\hline \multicolumn{3}{|c|}{ Main plots - Phosphorus levels $\left(\mathrm{kg} \mathrm{ha}^{-1}\right)$ to sunhemp } \\
\hline Control & 6.4 & 8.2 \\
\hline 10 & 6.5 & 8.2 \\
\hline 20 & 6.6 & 8.8 \\
\hline 30 & 6.7 & 8.9 \\
\hline 40 & 6.7 & 9.1 \\
\hline SEm \pm & 0.1 & 0.2 \\
\hline $\mathrm{CD}(\mathrm{P}=0.05)$ & NS & NS \\
\hline CV (\%) & 8.9 & 12.2 \\
\hline \multicolumn{3}{|c|}{ Sub- plots - Nitrogen levels $\left(\mathrm{kg} \mathrm{ha}^{-1}\right)$ to sweet corn } \\
\hline 60 & 6.5 & 8.7 \\
\hline 80 & 6.6 & 8.7 \\
\hline 100 & 6.6 & 8.7 \\
\hline 120 & 6.6 & 8.6 \\
\hline $\operatorname{SEm} \pm$ & 0.1 & 0.1 \\
\hline $\mathrm{CD}(\mathrm{P}=0.05)$ & NS & NS \\
\hline CV (\%) & 9.1 & 8.8 \\
\hline \multicolumn{3}{|c|}{ Interaction (P×N) } \\
\hline SEm \pm & 0.3 & 1.1 \\
\hline $\mathrm{CD}(\mathrm{P}=0.05)$ & NS & NS \\
\hline
\end{tabular}


Table.3 Crude fibre (\%) of sweet corn as influenced by phosphorus levels to preceding green manure crop and nitrogen levels to sweet corn

\begin{tabular}{|c|c|c|}
\hline \multirow[t]{2}{*}{ Treatment } & \multicolumn{2}{|c|}{ Crude fibre } \\
\hline & Straw & Grain \\
\hline \multicolumn{3}{|c|}{ Main plots - Phosphorus levels $\left(\mathrm{kg} \mathrm{ha}^{-1}\right)$ to sunhemp } \\
\hline Control & 23.5 & 3.4 \\
\hline 10 & 25.6 & 3.7 \\
\hline 20 & 28.5 & 4.4 \\
\hline 30 & 30.4 & 4.7 \\
\hline 40 & 32.6 & 5.6 \\
\hline SEm \pm & 0.5 & 0.1 \\
\hline $\mathrm{CD}(\mathrm{P}=0.05)$ & 1.8 & 0.3 \\
\hline CV $(\%)$ & 8.4 & 10.4 \\
\hline \multicolumn{3}{|c|}{ Sub- plots - Nitrogen levels $\left(\mathrm{kg} \mathrm{ha}^{-1}\right)$ to sweet corn } \\
\hline 60 & 26.5 & 4.1 \\
\hline 80 & 27.9 & 4.3 \\
\hline 100 & 28.7 & 4.4 \\
\hline 120 & 29.2 & 4.6 \\
\hline SEm \pm & 0.5 & 0.1 \\
\hline $\mathrm{CD}(\mathrm{P}=\mathbf{0 . 0 5})$ & 1.5 & 0.3 \\
\hline $\mathrm{CV}(\%)$ & 8.7 & 12.2 \\
\hline \multicolumn{3}{|c|}{ Interaction $(\mathbf{P} \times \mathbf{N})$} \\
\hline $\operatorname{SEm} \pm$ & 1.2 & 0.2 \\
\hline $\mathrm{CD}(\mathrm{P}=0.05)$ & NS & NS \\
\hline
\end{tabular}


Table.4 Total ash content (\%) at the time of harvest in sweet corn as influenced by phosphorus levels to preceding green manure crop and nitrogen levels to sweet corn

\begin{tabular}{|c|c|c|}
\hline \multirow[t]{2}{*}{ Treatment } & \multicolumn{2}{|c|}{ Total ash content } \\
\hline & Straw & Grain \\
\hline \multicolumn{3}{|c|}{ Main plots - Phosphorus levels $\left(\mathrm{kg} \mathrm{ha}^{-1}\right)$ to sunhemp } \\
\hline Control & 7.2 & 13.0 \\
\hline 10 & 9.1 & 14.2 \\
\hline 20 & 11.7 & 16.7 \\
\hline 30 & 14.1 & 19.1 \\
\hline 40 & 15.3 & 20.3 \\
\hline SEm \pm & 0.3 & 0.2 \\
\hline $\mathrm{CD}(\mathrm{P}=0.05)$ & 1.0 & 0.8 \\
\hline $\mathrm{CV}(\%)$ & 11.4 & 6.5 \\
\hline \multicolumn{3}{|c|}{ Sub- plots - Nitrogen levels $\left(\mathrm{kg} \mathrm{ha}^{-1}\right)$ to sweet corn } \\
\hline 60 & 11.1 & 16.3 \\
\hline 80 & 11.1 & 16.4 \\
\hline 100 & 11.5 & 16.7 \\
\hline 120 & 12.3 & 17.3 \\
\hline SEm \pm & 0.2 & 0.2 \\
\hline $\mathrm{CD}(\mathrm{P}=0.05)$ & 0.8 & 0.7 \\
\hline CV (\%) & 11.2 & 7.1 \\
\hline \multicolumn{3}{|c|}{ Interaction $(\mathbf{P} \times \mathbf{N})$} \\
\hline $\operatorname{SEm} \pm$ & 0.6 & 0.5 \\
\hline $\mathrm{CD}(\mathrm{P}=0.05)$ & NS & NS \\
\hline
\end{tabular}




\section{Quality parameters}

In the present study, it was observed that all the Quality parameters (Table 2-4) viz., crude protein, crude fibre, Total ash content at harvest were increased with increase in application of $\mathrm{P}_{2} \mathrm{O}_{5}$ to the preceeding sunhemp green manure crop from control to $40 \mathrm{~kg} \mathrm{P}_{2} \mathrm{O}_{5} \mathrm{ha}^{-1}$. Among the nitrogen levels to sweet corn the highest crude protein $(6.6 \%)$ was recorded with $120 \mathrm{~kg} \mathrm{~N} \mathrm{ha}^{-1}$ the lowest crude protein $(6.5 \%)$ with $60 \mathrm{~kg} \mathrm{~N} \mathrm{ha}^{-1}$ at harvest in straw and the highest crude protein $(8.7 \%)$ was recorded with $120 \mathrm{~kg} \mathrm{~N} \mathrm{ha}^{-1}$ the lowest crude protein $(8.6 \%)$ with $60 \mathrm{~kg} \mathrm{~N} \mathrm{ha}^{-1}$ at harvest in grain. Numerically higher crude protein at higher nitrogen fertilizer might be due to high nitrogen concentration in plant at higher fertility levels thus emphasizing the fact that nitrogen plays a role in protein synthesis. The nitrogen content in straw and grain were not significantly influenced by the different treatments tried in the trail. As the crude protein content was estimated by multiplying nitrogen content with the factor 6.25 , hence the non-significant differences in crude protein content in straw and grain. The crude fibre (29.5\%) was recorded with $120 \mathrm{~kg}$ $\mathrm{N}$ ha $^{-1}$ and lowest $(26.5 \%)$ crude fibre at harvest in straw respectively was registered in $60 \mathrm{~kg} \mathrm{~N} \mathrm{ha}^{-1}$ and the crude fibre (4.6\%) was recorded with $120 \mathrm{~kg} \mathrm{~N} \mathrm{ha}^{-1}$ and lowest (4.1 $\%$ ) crude fibre at harvest in grain respectively was registered in $60 \mathrm{~kg} \mathrm{~N} \mathrm{ha}^{-1}$. Phosphorus fertilization to preceeding sunhemp resulting in higher drymatter accumulation and after incorporation added higher organic matter at higher levels. The high organic matter incorporated facilitated all the essential plant nutrients more available to the succeeding sweet corn which exhibited increased growth. Applying fertilizer nitrogen at high levels too favoured higher growth and development this might have encouraged the sweet corn plant to have more photosynthetic area and produced more of the photosynthates. These increased carbohydrates during metamorphoses could have stored in the form of cellulose and hemicelluloses in cell walls and this could be ascribed as the reason for high crude fibre in sweet corn. Significantly the lowest $(11.1 \%)$ and the highest $(12.3 \%)$ total ash content were registered in $120 \mathrm{~kg} \mathrm{~N}$ $\mathrm{ha}^{-1}$ and $60 \mathrm{~kg} \mathrm{~N} \mathrm{ha}^{-1}$ in straw. Significantly the lowest $(16.3 \%)$ and the highest $(17.3 \%)$ total ash content were registered in $120 \mathrm{~kg} \mathrm{~N}$ $\mathrm{ha}^{-1}$ and $60 \mathrm{~kg} \mathrm{~N} \mathrm{ha}^{-1}$ in grain. Increase in ash contents (\%) might be due to increase in growth parameters and also drymatter production in the higher available nutrients. These findings are in conformity with Ayub et al., (2003), Bhatt. (2012) and Rashid and Iqbal. (2012).

\section{References}

Ayub, M., Nadeem, M.A., Ahmad, R and Javaid F. 2003. Response of maize fodder to different nitrogen levels and harvesting times. Pakistan Journal of Life Social Sciences. 1: 45-47

Bhatt, P.S. 2012. Response of sweet corn hybrid to varying plant densities and nitrogen levels. African Journal of Agricultural Research. 7(46): 61586166.

Eajaz, A.D., Amarjit, S.H., Ashim, D and Hanuman, S.J. 2014. Growth, yield and economic returns from the dual purpose baby corn (Zea mays) under different planting geometry and nitrogen levels. Indian Journal of Agronomy. 59(3): 468-470.

Gomez, K.A and Gomez, A.A. 1984. Statistical procedures in Agricultural Research. New York Chichester Wiley. 1984 2nd edition. pp-680.

Kar, P.P., Barik, K.C., Mahapatra, P.K., Garnayak, L.M., Rath, B.S., Bastia, D.K and Khanda, C.M. 2006. Effect of planting geometry and nitrogen on yield, economics and nitrogen uptake of 
sweet corn (Zea mays). Indian Journal of Agronomy. 51(1): 43-45.

Rashid, M and Iqbal. M. 2012. Effect of phosphorus fertilizer on the yield and quality of maize (Zea mays. L) fodder on clay loam soil. The Journal of Animal and Plant Sciences. 22(1): 1018-7081.

Shankar, L.G., Ganpat, L.S and Jain, H.K. 2013. Performance of baby corn (Zea mays L.) as influenced by spacing, nitrogen fertilization and plant growth regulators under sub humid condition in Rajasthan, India. African Journal of Agricultural Research. 8(12): 11001107.

Singh, U., Saad, A.A., Ram, T., Chand, L., Mir, S.A and Aga, F.A. 2012. Productivity, economics and nitrogen use efficiency of sweet corn (Zea mays L. saccharata) as influenced by planting geometry and nitrogen fertilization. Indian Journal of Agronomy. 57: 43-48.

\section{How to cite this article:}

Kavya, T., B. Venkateswarlu, P.V.N. Prasad and Prasad, P.R.K. 2018. Yield and Quality Parameters as Influenced by Nutrient Management Studies in Sweet Corn. Int.J.Curr.Microbiol.App.Sci. 7(10): 743-750. doi: https://doi.org/10.20546/ijcmas.2018.710.082 